\title{
Aplikasi Metodologi Mengenal Alam oleh Daud al-Fatani dalam Isu Penentuan Kenampakan Anak Bulan
}

\author{
Mohammaddin Abdul Niri \\ Universiti Malaya, mohammaddin@um.edu.my \\ Sa'adan Man \\ Universiti Malaya, saadan@um.edu.my \\ Che Zarrina Sa'ari \\ Universiti Malaya, zarrina@um.edu.my \\ Mohd Saiful Anwar Mohd Nawawi \\ Universiti Malaya, saifulanwar@um.edu.my
}

\begin{abstract}
Abstrak
Setiap kaedah penentuan kenampakan anak bulan mempunyai fungsi tersendiri. Fungsi itu dapat dijelaskan berasaskan metodologi mengenal alam. Dalam penelitian ini, metodologi mengenal alam yang dikemukakan oleh Daud al-Fatani diaplikasikan untuk menjelaskan fungsi berkenaan. Pengumpulan data dalam kajian ini adalah berdasarkan metode dokumentasi, manakala analisis data adalah berasaskan metode analisis kandungan. Hasil kajian mendapati kaedah hisab adalah zannī yang lebih kuat berbanding kaedah rukyah tetapi ia lebih lemah berbanding kaedah istikmal. Sehubungan itu, fungsi kaedah hisab hanya sebagai pengesah dan penafi kepada laporan cerapan terutamanya apabila menentukan kenampakan anak bulan bagi bulan Ramadan, Syawal dan Zulhijjah.
\end{abstract}

Kata kunci: anak bulan, Daud al-Fatani, astronomi Islam, metode berfikir

\section{Application of the Methodology to Know the Universe by Daud al-Fatani in Determining the Crescent Visibility Issue}

\section{Abstract}

Each method of determining the crescent's visibility has its own function. The function can be explained based on the methodology to know the universe. In this study, the methodology to know the universe as presented by Daud al-Fatani is applied to elucidate the function. Data collection in this study is based on the documentation method, while data analysis is according on content analysis method. The study found that the calculation method is conjecture (zannī) which is stronger than the observational method but it is weaker than the rounding method (istikmal). Accordingly, the calculation method can be function only as a verifier and a disclaimer to the observation report primarily when determining the crescent's visibility for the month of Ramadan, Syawal and Zulhijjah.

Keywords: crescent, Daud al-Fatani, Islamic astronomy, thinking method 


\section{Pendahuluan}

Kenampakan anak bulan merupakan asas rujukan dalam sistem kalendar Islam untuk memulakan bulan baru. Pengkajian terhadapnya lebih awal lagi telah dilakukan sejak zaman Babylon, kemudian pada zaman tamadun Yunani, Rom, Yahudi, Mesir, Aztec, Inca, Cina dan Hindu ${ }^{1}$. Pengkajian itu merupakan satu tugas yang mencabar kerana ia melibatkan pelbagai faktor yang perlu diambil kira seperti faktor astronomi, faktor meteorologi dan faktor psikologi. Oleh sebab itu, terdapat pelbagai kaedah telah diformulasikan oleh para sarjana untuk menentukan kebolehnampakan anak bulan yang pertama selepas fasa ijtimak di mana ia meliputi lapangan teoretikal hinggalah eksperimental ${ }^{2}$.

Walau bagaimanapun, kepelbagaian kaedah itu sering membawa kepada konflik pemikiran dan lazimnya ia berlaku ekoran daripada kegagalan memahami fungsi suatu kaedah itu sendiri ${ }^{3}$. Hal demikian menuntut agar fungsi setiap kaedah dinyatakan dengan kemas dan berpandu kepada metode berfikir yang jelas. Memandangkan fenomena kenampakan anak bulan adalah suatu gejala alam tabii, maka adalah lebih wajar untuk mengaplikasikan metode mengenal alam. Untuk itu, kajian ini membincangkan aspek fungsi terbabit dengan menerapkan metode berfikir Daud al-Fatani tentang alam.

\section{Penentuan Kenampakan Anak Bulan}

Berdasarkan nas-nas syarak, seperti ditunjukkan di bawah, yang berkaitan dengan penentuan awal bulan qamari, para ulama bersependapat bahawa apabila anak bulan dapat dicerap pada hari ke-29 Hijrah khususnya bagi bulan Ramadan, Syawal dan Zulhijjah, maka hari keesokannya boleh ditetapkan sebagai satu hari bulan Hijrah yang baharu.

1 Ilyas, Kalendar Islam Antarabangsa (Kuala Lumpur: Dewan Bahasa dan Pustaka, 1999), 30.

2 Ayman S. Kordi, "The Psychological Effect on Sightings of the New Moon", The Observatory, 123 (2003), 219-222. Lihat juga Bradley E. Schaefer, "Visibility of the Lunar Crescent", Quarterly Journal of the Royal Astronomical Society, 29 (1988), 511.

3 Mohammad Ilyas, Kalendar Islam Antarabangsa, 12. 


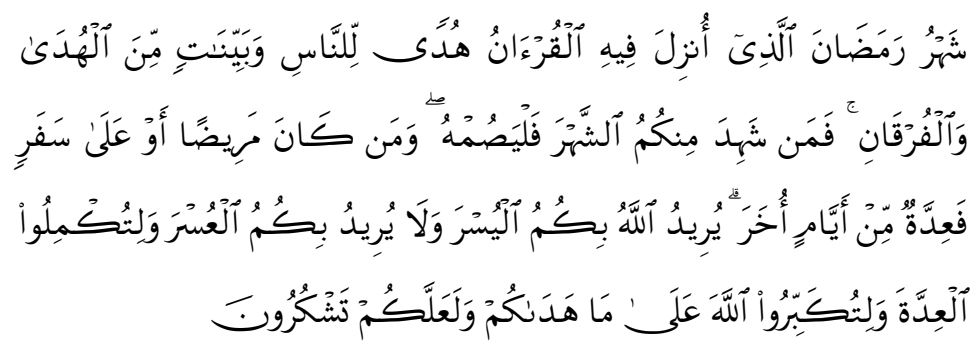

Al-Baqarah 2:185

Terjemahan: Sesiapa antara kamu yang menyaksikan anak bulan Ramadan (atau mengetahuinya), maka hendaklah ia berpuasa bulan itu.

Daripada 'Abd Allāh Ibn 'Umar r.a berkata: Rasulullah SAW bersabda:

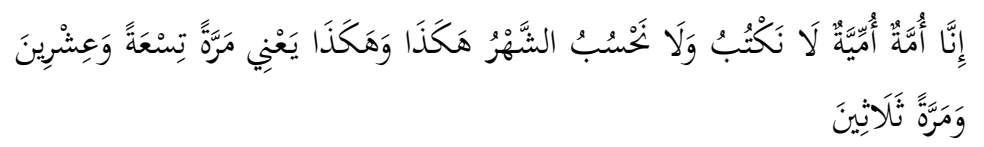

Terjemahan: Sesungguhnya kami umat yang buta huruf, tidak tahu menulis dan tahu mengira, bulan adalah sekian sekian iaitu sesekali 29 hari dan sesekali lagi 30 hari. $^{4}$

Daripada Muhammad bin Ziyād r.a berkata: Aku mendengar Abū Hurayrah r.a berkata: Rasulullah SAW bersabda:

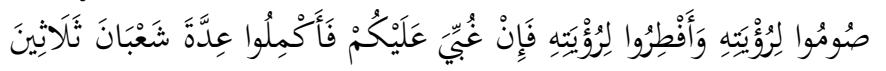

Terjemahan: Berpuasalah kamu apabila melihat anak bulan dan berbukalah (berhari raya) sekiranya melihat anak bulan. Sekiranya mendung, maka sempurnakanlah 30 hari Syaaban. ${ }^{5}$

Daripada 'Abd Allāh Ibn 'Umar r.a berkata: Rasulullah SAW bersabda:

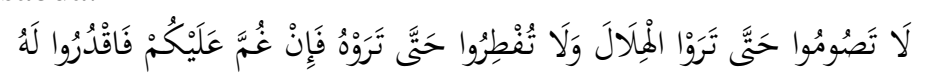

Terjemahan: Jangan kamu berpuasa sehingga kamu melihat anak bulan dan jangan kamu berbuka sehingga kamu melihat anak bulan. Sekiranya mendung, maka takdirkanlah ia. ${ }^{6}$

4 Hadith riwayat al-Bukhārī, Kitāb al-Ṣawm, Bāb Qawl al-Nabiy Șalla Allāh 'Alayh wa Sallam, Lā Naktub wa lā Naḥsub, no. Hadith 1913, Al-Bukhārī, "Șah̄inh al-Bukhārī", 149.

5 Hadith riwayat al-Bukhārī, Kitāb al-Ṣawm, Bāb Qawl al-Nabiy Șalla Allāh 'Alayh wa Sallam, Idhā Ra'aitumu al-Hilāl Fașūmū, wa Idhā Ra'aitumūhu Fafțirū, no. Hadith 1909, Al-Bukhārī, "Șaḥịh al-Bukhārī”, 149. 
Bagaimanapun, apabila anak bulan tidak kelihatan pada hari tersebut, terdapat perbezaan pandangan dalam kalangan ulama terhadap kaedah yang perlu digunakan untuk menetapkan awal bulan Hijrah ekoran daripada dalil-dalil syarak yang menjadi sandaran merupakan nas zannī. Terdapat dua pandangan utama dalam hal ini iaitu ${ }^{7}$ :

Pertama; sekiranya anak bulan tidak kelihatan maka bulan qamari dilengkapkan kepada 30 hari dan bukannya ditaqdirkan kepada hisab. Pandangan ini dipilih oleh jumhur ulama salaf dan khalaf antaranya Abū Hanīfah (m. 150H/767M), Mālik (m. 179H/795M), al-Shāfi'‘̄ (m. 204H/820M), al-Nawāwī (m. 676 H/1278M) dan Ibn Hajar al-'Asqalānī (m. 852H/1449M). Penggenapan bilangan bulan qamari kepada 30 hari dikenali sebagai kaedah istikmal (istikmāl $)^{8}$.

Kedua; sekiranya anak bulan tidak kelihatan maka penentuan dibuat menerusi kaedah hisab iaitu kiraan astronomi. Antara ulama yang berpandangan sedemikian ialah Muṭarrif bin 'Abd Allāh alMālikī (m. 220H/835M), Ibn Qutaybah (m. 276H/885M) dan Abū al-'Abbās bin Surayj al-Shāfi'î (m. 306H/919M)' . Antara ulama mutakhir yang turut menerima kaedah hisab untuk menentukan kenampakan anak bulan pada hari ke-29 qamari ialah Muhammad Bakhīt al-Muțī's (m. 1354H/1935M) $)^{10}$, Ṭanțāwī Jawharī (m. 1358H/1940M) ${ }^{11}$ Aḥmad Muhammad Shākir (m. 1377H/1958M) ${ }^{12}$, Muștafā Aḥmad al-Zarqā'’ (m. 1419H/1999M) ${ }^{13}$ dan Yūsuf al-Qaraḍāwīi ${ }^{14}$.

${ }^{6}$ Hadith riwayat al-Bukhārī, Kitāb al-Șawm, Bāb Qawl al-Nabiy Șalla Allāh 'Alayh wa Sallam, Idhā Ra'aitumu al-Hilāl Fașūmū, wa Idhā Ra'aitumūhu Faftịūu, no. Hadith 1906, Al-Bukhārī, "Saḥīh al-Bukhārī”, 149.

7 Abū Zakariyyā Muhyē̄ al-Dīn al-Nawawī, al-Majmū' Sharh al-Muhadhdhab li al-Shīrāzī (Jeddah: Maktabah al-Irshād, 1980), 6:276; Al-'Asqalānī, Fath alBārī bi Syarh Șạ̄ịh al-Bukhārī, ed. 'Abd al-Qādir Syaibah al-Hamad (Riyadh: Maktabah al-Malik Fahd al-Wațaniyyah Atsnā' an-Nasyr, 2001), 142.

8 Al-Nawāwī, al-Majmū' Sharh al-Muhadhdhab li al-Shīrāzī, 6:276.

9 Yūsuf al-Qarḍāwī, Fiqh al-Ṣiyām (Kaherah: Maktabah al-Wahbah, 2006), 26.

${ }^{10}$ Muhammad Bakhīt al-Muțī' $\overline{1}$, Kitāb Irshād Ahl al-Millah ilā Ithbāt al-Ahillah (Kaherah: Mațba'ah Kurdistan al-'Ilmiyyah, 1911).

11 Țanțāwī Jawharī, al-Qur'ān wa al-'Ulūm al-'Asriyyah (Kaherah: Maṭba'ah Dār Ihyā' al-Kutub al-'Arabiyyah, 1923), 28-29.

12 Aḥmad Muhammad Shākir, Awā'il al-Shuhūr al- 'Arabiyya: Hal Yajūz Shar 'an Ithbātuhā bi al-Hisāb al-Falakī? Bahth Jadīd 'Ilmī Hurr (Kaherah: Dār alIstiqāmah, 1992), 1-29. 
Berdasarkan pandangan para ulama itu, jelas bahawa terdapat tiga kaedah penentuan kenampakan anak bulan. Pertama; kaedah rukyah atau cerapan di mana ia merupakan kaedah paling asas. Kedua; kaedah istikmal iaitu penggenapan bulan qamari menjadi 30 hari sekiranya anak bulan tidak kelihatan pada hari ke-29 qamari. Ketiga; kaedah hisab iaitu berasaskan kiraan astronomi di mana kenampakan anak bulan ditetapkan mengikut kriteria tertentu.

Dalam penyelidikan moden, pelbagai kriteria dibangunkan dan ia dapat diteliti dalam kajian Fotheringham ${ }^{15}$, Maunder ${ }^{16}$, Bruin $^{17}$, McNally $^{18}$, Schaefer $^{19}$, Odeh $^{20}$ dan Mohammad Ilyas ${ }^{21}$. Berdasarkan kajian Mohd Saiful Anwar Mohd Nawawi, ${ }^{22}$ terdapat tiga bentuk kriteria yang biasanya digunakan dalam penentuan kenampakan anak bulan untuk awal bulan Hijrah untuk realiti semasa pada hari ini. Pertama, kriteria ijtimak. Kedua, kriteria wujūd al-hilāl. Dan ketiga, kriteria imkān al-ru'yah.

${ }^{13}$ Mușțafā Aḥmad al-Zarqā', "Hawl I'timād al-Ḥisāb al-Falakī li Taḥdīd Bidāyah al-Shuhūr al-Qamāriyyā: Hal Yajūz Shar'an aw Lā Yajūz?," dalam Majjallāt Majma' al-Fiqh al-Islāmī (Dawrah al-Thāniyah li Mu'tamar Majma' al-Fiqh Islāmī, 1986), 2: 927-936.

${ }^{14}$ Yūsuf al-Qaraḍāwī, Kayf Nata'āmal ma'a al-Sunnah al-Nabawiyyah (Kaherah: Dār al-Shuruq, 2005), 165-173.

15 J. K. Fotheringham, "The Visibility of The Lunar Crescent", The Observatory 44 (1921); J. K Fotheringham, "On the Smallest Visible Phase of the Moon", Monthly Notices of the Royal Astronomical Society, no. 70 (1910).

${ }^{16}$ E. W. Maunder, "On the Smallest Visible Phase of the Moon", The Journal of the British Astronomical Association, no. 21 (1911).

${ }^{17}$ F. Bruin, "The First Visibility of the Lunar Crescent", Vistas in Astronomy, no. 21 (1977).

${ }^{18}$ D. McNally, "The Length of the Lunar Crescent", Royal Astron. Soc. Quarterly Journal 24, no. 4 (1983).

19 B. E. Schaefer, "An Algorithm for Predicting the Visibility of the Lunar Crescent," Bulletin of the American Astronomical Society 19.

${ }^{20}$ Mohammad Shaukat Odeh. "New Criterion for Lunar Crescent Visibility". Experimental Astronomy 18, no. 1-3 (2004): 39-64.

${ }^{21}$ Mohammad Ilyas, "Limiting Altitude Separation in The New Moon's First Visibility Criterion". Astronomy and Astrophysics 206, no. 1 (11 1988): 133135.; Mohammad Ilyas, "Lunar Crescent Visibility Criterion and Islamic Calendar." Quarterly Journal of the Royal Astronomical Society 35, no. 4 (12 1994): 425-461.

22 Mohd Saiful Anwar Mohd Nawawi, "Penilaian Semula Kriteria Kenampakan Anak Bulan di Malaysia, Indonesia Dan Brunei" (Tesis kedoktoran, Universiti Malaya, 2014), 63. 


\section{Fungsi Kaedah Penentuan Kenampakan Anak Bulan}

Berdasarkan penelitian pengkaji ${ }^{23}$, satu isu penting yang terus diberi perhatian oleh para ulama dan sarjana mutakhir ialah berkaitan dengan fungsi kaedah hisab dan kedudukannya dalam realiti semasa. Selaras dengan pandangan al-Subki $\overline{1}^{24}$, alQaraḍāwī ${ }^{25}$ berpendapat bahawa kaedah hisab hanya berfungsi sebagai penafi (nafi) kepada laporan cerapan kerana ia suatu yang putus dan tepat iaitu qaț' $i \bar{l}$, sedangkan laporan cerapan adalah

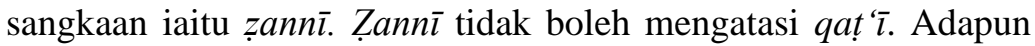
kaedah hisab tidak boleh menjadi isbat (ithbāt) iaitu pengesah kenampakan anak bulan kerana untuk fungsi itu ia bersifat zannī.

Menurut al-Qaraḍāwī, keadaan masyarakat Islam pada hari ini berbeza dengan masyarakat dahulu. Keadaan masyarakat semasa sudah celik dengan huruf dan angka. Oleh itu, cara yang lebih baik untuk mencapai objektif hukum iaitu menentukan awal bulan Hijrah adalah dengan menggunakan hisab iaitu kiraan astronomi. Sebaliknya dalam situasi masyarakat Islam dahulu kaedah istikmal lebih sesuai kerana sifatnya yang lebih ringkas dan memudahkan. Adapun penerimaan hisab dalam situasi hari ini perlu dilihat dari sudut keutamaan di mana kaedah hisab bersifat pasti (qat ‘ $\grave{\imath})$ sedangkan kaedah rukyah bersifat sangkaan $(\text { zann } \bar{\imath})^{26}$.

Pandangan bahawa kaedah hisab adalah qat ‘ $i$ turut diterima oleh Ahmad Muhammad Shākir ${ }^{27}$ dan Sharaf al-Quḍāh ${ }^{28}$. Menurut Shākir ${ }^{29}$, masyarakat Islam pada masa kini dari peringkat pakar

${ }^{23}$ Mohammaddin Abdul Niri et. al. "Kesan Penggunaan Hitungan Astronomi dan Alatan Moden dalam Cerapan Hilal di Malaysia: Satu Penelitian”. Jurnal Fiqh 9 (2012): 45-64; Mohd Saiful Anwar Mohd Nawawi, Mohammaddin Abdul Niri dan Mohd Zambri Zainuddin. "Kenampakan Anak Bulan di Teluk Kemang: Analisis Mengikut Pandangan Fiqh oleh Yusuf al-Qaradawi dan Perspektif Astronomi”. Jurnal Syariah 21, no. 1 (2013): 63-73.

${ }^{24}$ Taqī al-Dīn 'Alī bin 'Abd al-Kāfī al-Subkī, Fatāwā al-Subkī fi Furū' al-Fiqh al-Shāfi ‘̄ (Beirut: Dār al-Ma'rifah, 2004), 1: 209.

25 Al-Qaraḍ̄̄̄ī, Kayf Nata 'āmal ma 'a al-Sunnah al-Nabawiyyah, 172.

${ }^{26}$ Al-Qaraḍ̄̄wī, Kayf Nata 'āmal ma 'a al-Sunnah al-Nabawiyyah, 165.

${ }^{27}$ Shākir, Awā'il al-Shuhūr al-'Arabiyya: Hal Yajūz Shar'an Ithbātuhā bi alHisāb al-Falakī? Bahth Jadīd 'Ilmī Hurr 1-29; Ebrahim Moosa, "Shaykh Ahmmad Shākir and the Adoption of a Scientifically-Based Lunar Calendar," Islamic Law and Society 5, no. 1 (1998), t.h.

${ }^{28}$ Sharaf al-Quḍāh, "Thubūt al-Shahr al-Qamarī baina al-Ḥadīth al-Nabawī wa al-'Ilm al-Ḥadīth" dalam Majallah al-Dirāsah (Jāmi'ah Urdūn, 1999), 6-8.

${ }^{29}$ Moosa, "Shaykh Ahmad Shākir and the Adoption of a Scientifically-Based Lunar Calendar," t.h. 
hingga orang awam sudah mampu mempelajari hisab yang bersifat yakin dan qat ' $i$ dalam menentukan kenampakan anak bulan. Oleh itu, mereka boleh bersandar kepada kaedah hisab sepertimana masyarakat Islam dahulu bergantung kepada kaedah rukyah. Tambahan, kebanyakan umat Islam sudah boleh mengira maka penyebab hukum ('illah) iaitu buta huruf sudah tidak wujud lagi. Justeru, lebih utama mencari kaedah lain yang lebih pasti (al-yaqin al-thābit). Disebabkan itu, kaedah hisab perlu diterima dalam penentuan awal bulan (ithbāt al-ahillah). Kaedah hisab hanya boleh diketepikan bila kaedah tersebut menjadi sukar untuk ahli masyarakat.

Selanjutnya, al-Quḍāh menerangkan bahawa kaedah hisab bukanlah hanya sebagai penafi laporan cerapan semata-mata malah ia dapat berfungsi secara qat' $\bar{\imath}$ sebagai penafi dan isbat kenampakan anak bulan. Pandangan al-Subkī yang menjelaskan kaedah hisab adalah zannī untuk mengesahkan kenampakan anak bulan disangkal oleh al-Quḍāh. Menurut al-Quḍāh, hisab pada masa dahulu terutama abad pertama Islam sememangnya adalah zannī.

Bagaimanapun, setelah ilmu astronomi berkembang berabad lamanya dan mengalami proses pembaikan, kaedah perhitungan ilmu itu pada masa kini menjadi lebih tepat iaitu qat ' $i$. Sehinggakan maklumat hari, bulan, jam, minit dan saat kelahiran bulan ijtimak dapat diketahui selama ratusan tahun yang akan datang. Selanjutnya, maklumat itu dicetak dan diumumkan melalui program komputer dan talian internet. Kemajuan dalam ilmu astronomi jelas menunjukkan bahawa alam semesta dan fenomenanya yang berlaku adalah suatu yang tetap dan tidak berubah $^{30}$.

Merujuk perbezaan pandangan para ulama di atas, maka fungsi kaedah penentuan kenampakan anak bulan terutamanya kaedah hisab dan kedudukannya dalam realiti semasa dapat disimpulkan sebagaimana berikut:

1. Kaedah hisab adalah qat' $\bar{\imath}$ sebagai penafi kepada laporan cerapan dan zannī sebagai isbat kenampakan anak bulan.

2. Kaedah hisab adalah qat ‘ $i$ sebagai isbat dan penafi kenampakan anak bulan.

\footnotetext{
${ }^{30}$ Al-Quḍ̄h, "Thubūt al-Shahr al-Qamarī baina al-Hadīth al-Nabawī wa al- 'Ilm al-Hadith."
} 
3. Kaedah hisab lebih sesuai untuk realiti semasa kerana masyarakat Islam pada masa kini dilatari oleh kadar celik huruf yang tinggi.

4. Kaedah rukyah dan istikmal hanya sesuai untuk masyarakat Islam yang masih ummī iaitu memiliki kadar celik huruf yang rendah.

\section{Biografi Ringkas Daud al-Fatani}

Daud al-Fatani merupakan seorang tokoh ulama terkemuka di Alam Melayu. Nama penuh beliau ialah Wan Daud bin Syeikh Wan Abdullah bin Syeikh Wan Idris@ Tok Wan Derasid @ Syeikh Wan Senik bin Tok Wan Abu Bakar bin Tok Kaya Pandak bin Andi (Faqih) Ali Datuk Maharajalela ${ }^{31}$. Tempat kelahiran Daud al-Fatani yang lebih munasabah ialah Kg. Keresik, Patani. Adapun catatan tahun $1769 \mathrm{M} / 1183 \mathrm{H}$ untuk menunjukkan tarikh kelahiran Syeikh Daud al-Fatani adalah kurang tepat berdasarkan tarikh kematian guru-gurunya semasa beliau berada di Makkah. Misalnya, 'Isā bin Aḥmad al-Qāhirī al-Barrawī meninggal pada tahun $1768 \mathrm{M} / 1182 \mathrm{H}$ dan Muhammad bin 'Abd al-Karīm alSammān̄̄ al-Madān̄ pada tahun 1775M/1189H. Ramai para pengkaji berpandangan bahawa Daud al-Fatani berangkat ke Makkah ketika beliau masih remaja dan berguru dengan keduadua tokoh ulama itu ${ }^{32}$.

Dari sudut latar belakang keluarga, Daud al-Fatani merupakan anak sulung daripada enam orang adik beradik iaitu Wan Abd al-Qadir, Wan Abd al-Rasyid, Wan Idris, Haji Wan Nik dan seorang perempuan. ${ }^{33}$ Keluarga beliau kemudiannya berkembang dan tersebar di berbagai tempat di Alam Melayu sehingga ke Makkah. Antara tokoh ulama masyhur yang

31 Terdapat pelbagai bentuk pengungkapan nama penuh beliau. Lihat dalam Wan Mohd. Shaghir Abdullah, Syeikh Daud bin Abdullah al-Fatani: Ulama' dan Pengarang Terulung Asia Tenggara (Shah Alam: Hizbi, 1990), 9-11. Bandingkan dengan Ahmad Fathy al-Fatani, Ulama Besar dari Patani (Bangi: Universiti Kebangsaan Malaysia, 2002), 25-26.

${ }^{32}$ Fauzi Deraman, Hadith dalam karya Syeikh Daud al-Fatani (Kuala Lumpur: Dewan Bahasa dan Pustaka, 2010), 36.

${ }^{33}$ Wan Mohd. Shaghir Abdullah, "Sejarah Ringkas Syeikh Daud bin Abdullah al-Fatani dan Karya-karyanya," dalam Kertas Kerja Nadwah Ilmiah Tokoh Ulama Peringkat Kebangsaan Kali ke-4, Pusat Islam Kuala Lumpur, 17-19 Disember, 199113. 
merupakan ahli keluarga beliau ialah Nik Dir al-Fatani (182998M) dan Nik Mat Kecik al-Fatani (1844-1915M) ${ }^{34}$. Dari segi sahsiahnya, hasil penulisan Syeikh Daud al-Fatani menunjukkan bahawa beliau merupakan seorang yang sangat merendah diri, sentiasa mengaku banyak berdosa, mengaku lemah, tidak berdaya dan banyak bergantung kepada Allah SWT. Hasil tulisannya itu menjadikan beliau cukup dikenali dengan sifat warak $^{35}$.

Mengimbas latar belakang keilmuan Daud al-Fatani, beliau pada peringkat awal memperolehi pendidikan daripada keluarganya sendiri yang memang terkenal alim dalam agama. Bapa, bapa saudaranya dan datuknya iaitu Syeikh Abdullah, Syeikh Safiyudin dan Syeikh Idris merupakan tokoh ulama yang dikenali di Patani. Selain itu, beliau turut berguru daripada ulama tempatan lain serta yang datang dari Timur Tengah khususnya dari Yaman $^{36}$. Beliau juga mengikuti pengajian pondok di Patani kemudiannya belajar di Aceh menjadi murid kepada Muhammad Zain bin Faqih Jalaluddin al-Asyi selama dua tahun sebelum beliau berangkat ke Hijjaz dan menetap di sana dalam jangka waktu yang panjang sekitar 30 tahun $^{37}$.

Daud al-Fatani telah melahirkan ramai murid yang bertebaran di Alam Melayu dan beliau diakui sebagai tokoh ulama yang berpengaruh dalam sejarah Islam di Patani. Beliau telah menghasilkan karya dalam pelbagai bidang ilmu seperti pemikiran Islam iaitu akidah, perundangan Islam iaitu fiqh, kerohanian Islam iaitu tasawuf, sejarah, sastera, zikir, fadilat amalan dan lain-lain. Pengkaryaan itu jelas membuktikan beliau adalah seorang sarjana Islam prolifik dan berkarya dalam bahasa Arab dan Melayu. Berbanding karyanya dalam bahasa Arab, karyanya dalam bahasa Melayu lebih banyak tersebar dan meluas dipelajari di Alam Melayu. Berhubungan dengan kewafatannya, al-Fatani meninggal sekitar tahun $1847 \mathrm{M}$ bersamaan dengan 1265H. Beliau

${ }^{34}$ Kedua-duanya merupakan cucu saudara Daud al-Fatani. Lihat dalam Ahmad Fathy al-Fatani, Ulama Besar dari Patani, 44, 74.

${ }^{35}$ Fauzi Deraman, Hadith dalam karya Syeikh Daud al-Fatani, 40.

${ }^{36}$ Ahmad Fathy al-Fatani, Ulama Besar dari Patani, 26; Virginia Matheson dan M. Barry Hooker. "Jawi Literature in Patani: The Maintenance of an Islamic Tradition". Journal of the Malaysian Branch of the Royal Asiatic Society 61, no. 1 (1988): 1-86.

${ }^{37}$ Wan Mohd. Shaghir Abdullah, "Sejarah Ringkas Syeikh Daud bin Abdullah al-Fatani dan Karya-karyanya," 32 . 
dimakamkan di Taif bersebelahan dengan makam Sayyidina 'Abd Allāh bin 'Abbās iaitu sepupu Rasulullah SAW ${ }^{38}$.

\section{Metodologi Mengenal Alam oleh Daud Al-Fatani}

Dalam karyanya al-Durr al-Thamin, Daud al-Fatani mentakrifkan alam sebagaimana berikut:

Maka makna tasawwur itu mendapat kejadian suatu dengan tiada dihukumkan atasnya dengan nafi atau ithbāt seperti kita tasawwurkan makna alam iaitu tiap-tiap yang maujud yang lain daripada Allāh Ta'ālā. Maka makna taṣdīq itu iaitu mendapatkan kejadian suatu serta kita hukumkan atasnya dengan nafi atau ithbāt seperti kita kata alam ini baharu dan ini bukan qadìm. ${ }^{39}$

Berdasarkan takrifan Daud al-Fatani itu, jelas bahawa metodologi beliau untuk mengenal alam berasaskan pendekatan tasdiq iaitu pembenaran yang terdiri daripada nafi (nafi) dan isbat (ithbāt). Nafi merujuk kepada penafian atau penolakan, manakala isbat merujuk kepada penetapan, pengesahan atau pengukuhan. Walaupun kaedah pembenaran nafi dan isbat ada digunakan dalam ilmu mantik ${ }^{40}$, ia bukan bermaksud formulasi kaedah itu datangnya secara mutlak daripada akal. Ini kerana ia juga wujud pada syarak ${ }^{41}$ dan itu lebih mustahak diketengahkan. Kaedah itu terkandung dalam nas wahyu bagi menyatakan konsep ketuhanan dalam agama Islam terutamanya aspek wahdāniyyah dan tanzīh. Mengenai wahdāniyyah Allah SWT, kaedah itu dipaparkan menerusi kalimah tauhid lā ilāha illā Allāh. Hal ini diterangkan lebih lanjut oleh Daud al-Fatani dalam al-Durr al-Thamin:

Ketahui olehmu bahawa adalah pada kalimah lā ilāha illā Allāh itu meliputi atasnya nafì dan ithbāt. Maka yang

${ }^{38}$ Wan Mohd. Shaghir Abdullah, "Sejarah Ringkas Syeikh Daud bin Abdullah al-Fatani dan Karya-karyanya," 23.

${ }^{39}$ Daud bin Abdullah al-Fatani, al-Durr al-Thamin, 7; Daud bin Abdullah alFatani, al-Durr al-Thamīn: Permata Yang Indah, 19.

${ }^{40}$ Dalam konteks ilmu mantik, konsep ilmu yang baharu iaitu ilmu makhluk diterangkan terdiri daripada tasawwur dan tasdiq. Tasawwur bermaksud pemahaman terhadap suatu perkataan tanpa diberikan hukuman nafi atau isbat. Tasdiq pula merujuk kepada hukum nafi atau isbat. Al-Maydān̄̄, Dawābit alMa'rifah wa Ușūl al-Istidlāl wa al-Munāzarah (Damsyik: Dār al-Qalam, 1993), 18.

${ }^{41}$ Daud bin Abdullah al-Fatani, al-Durr al-Thamin, 7; Daud bin Abdullah alFatani, al-Durr al-Thamin: Permata Yang Indah, 20. 
dinafikan itu tiap-tiap hakikat ketuhanan yang lain daripada Allāh Ta'ālā. Maka yang dinafikan itu tiada ada wujud pada hakikatnya pada akal dan syarak tetapi adalah tatkala makna Ilah itu kulli, maka taqdir wujudnya kemudian maka nafikan dia. Dengan sebab itulah sah kita isbatkan dengan kata illā Allāh sebab Ilah itu kullī dan Allāh itu juz' $\bar{\imath}$. Dan sahlah kita istithna'kan juz'̄̄ itu daripada kull, , maka yang diisbatkan daripada demikian hakikat itu iaitu zat yang satu, zat Allāh Tuhan kita Jalla Jalāluh. ${ }^{42}$

Dalam karyanya Diya al-Murīd:

Ketahui olehmu bahawasanya adalah lā ilāha illā Allāh itu terkandung atas nafi dan ithbät, maka yang dinafikan dengan lā ilāha itu tiap-tiap satu daripada hakikat ketuhanan yang lain daripada Allāh 'Azza wa Jalla dan yang diithbātkan dengan illā Allāh daripada demikian hakikat itu Tuhan yang esa lagi tunggal iaitu Allāh Ta'ālā dan didatangkan dengan mengisbatkan itu dengan lafaz illā kerana menyimpankan hakikat ketuhanan atas Allāh Ta'ālā. Ertinya tiada dapat ada demikian hakikat ketuhanan itu bagi yang lain daripada Allāh Ta'ālā pada akal dan pada syarak sekali-kali. ${ }^{43}$

Berkaitan dengan aspek tanzīh, kaedah nafi dan isbat terkandung dalam ayat 11, surah al-Shūrā. Ayat laisa kamithlihī shay' menunjukkan konteks nafi, manakala isbat terkandung dalam ayat wa huwa al-samī' al-bașīr ${ }^{44}$.

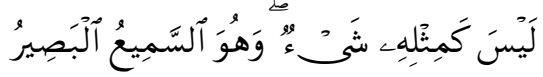

Al-Shūrā 42: 11

Terjemahan: Tidak ada sesuatu pun yang serupa dengan Dia, dan Dia yang Maha Mendengar dan Melihat.

Selain daripada itu, dapat diteliti bahawa Daud al-Fatani juga mengambil kira aspek cerapan yang dipaparkan menerusi penekanannya terhadap tilik. Tilik merujuk kepada perbuatan

${ }^{42}$ Daud bin Abdullah al-Fatani, al-Durr al-Thamin, 84; Daud bin Abdullah alFatani, al-Durr al-Thamin: Permata Yang Indah, 257.

${ }^{43}$ Daud bin Abdullah Daud bin Abdullah al-Fatani, Diyā al-Murīd (Hāmish alDurr al-Thamīn) (Patani: Maṭba'ah Bin Halābī, t.t), 7-8.

${ }^{44}$ Daud bin Abdullah al-Fatani, al-Durr al-Thamin, 50; Daud bin Abdullah alFatani, al-Durr al-Thamin: Permata Yang Indah, 152. 
melihat dengan teliti dan bersungguh-sungguh mencakupi pengamatan zahir dan batin. ${ }^{45}$

Maka tilik olehmu hai mukallaf kepada dirimu, kemudian berpindah tilikmu itu bagi alam yang di atas, kemudian maka alam yang di bawah. ${ }^{46}$

Kemudian maka tilik pula kepada tujuh petala langit daripada bulan dan matahari dan bintang, setengah merah, setengah kuning, setengahnya berjalan, setengahnya tetap ada baginya pihak yang tertentu, setengahnya bercahaya-cahaya, setengahnya kelam, maka sekaliannya menunjukkan baharu lagi berkehendak kepada yang menjadikan dia. ${ }^{47}$

Maka kepada dirimu yakni tilik olehmu kepada dirimu yakni kelakuan tubuh kamu kerana bahawasanya ia terlebih hampir segala perkara kepadamu. ${ }^{48}$

Dari sudut itu, jelas bahawa metode berfikir Daud al-Fatani untuk memahami tabiat alam ini dan hakikatnya bukan sekadar dengan menelaah kitab sahaja tetapi perlu membuat cerapan terhadap alam maujud dari alam angkasa sebagai alam makro, hinggalah merenung diri sebagai alam mikro. Signifikannya untuk bidang astronomi Islam, maka pengertian cerapan menjadi lebih kemas dan tidak hanya terbatas secara mata kasar (naked-eye) atau melalui ujikaji sistematik sahaja malah dilengkapkan dengan renungan mata hati.

Berpandukan metodologi mengenal alam oleh Daud alFatani, fenomena alam dan hubungan sebab-akibatnya diterangkan sebagai hukum adat. ${ }^{49}$ Dalam kerangka hukum itu, sebab-akibat tidak memberikan bekas dan ia tidak mempunyai hubungkait yang

${ }^{45}$ Dalam Kamus Dewan, tilik ditakrifkan sebagai pelihatan yang teliti dan sungguh-sungguh. Baharom et al., Kamus Dewan, 1683. Berdasarkan Kamus Besar Bahasa Indonesia, tilik didefinisikan sebagai penglihatan yang teliti terutama penglihatan dengan mata batin. Kamus Besar Bahasa Indonesia, laman sesawang Pusat Bahasa, Departemen Pendidikan Nasional Republik Indonesia, dicapai 30 Jun 2014, http://kbbi.web.id/tilik, entri “tilik".

46 Daud bin Abdullah al-Fatani, al-Durr al-Thamin, 17; Daud bin Abdullah alFatani, al-Durr al-Thamin: Permata Yang Indah, 46.

${ }^{47}$ Daud bin Abdullah al-Fatani, al-Durr al-Thaminn, 17; Daud bin Abdullah alFatani, al-Durr al-Thamin: Permata Yang Indah, 47.

${ }^{48}$ Daud bin Abdullah al-Fatani, al-Durr al-Thamīn, 17; Daud bin Abdullah alFatani, al-Durr al-Thamin: Permata Yang Indah, 47.

49 Daud bin Abdullah al-Fatani, al-Durr al-Thamin, 9; Daud bin Abdullah alFatani, al-Durr al-Thamin: Permata Yang Indah, 25. 
muktamad. Apa yang dicerap, dialami kemudian difahami oleh individu sebenarnya merupakan persepsi minda (dhihn) kerana melihat fenomena sebab-akibat secara berulang-ulang. Pengulangan itu kemudiannya mempengaruhi psikologi individu dan diterima sebagai kebiasaan.

Oleh sebab itu, apabila suatu keputusan yang diperolehi menerusi ujikaji saintifik mengandungi nilai ketepatan yang tinggi untuk menjelaskan suatu fenomena sebab-akibat, maka ia hanya menunjukkan nilai kemungkinan atau kebarangkalian yang tinggi untuk fenomena tersebut berlaku dan nilai itu pula mengatasi keraguan yang munasabah. Ia bukannya bersifat fakta muktamad untuk membuktikan bahawa fenomena alam itu pasti berlaku. Adapun keputusan ujikaji yang mencapai status fakta saintifik, ia dapat diterima sebagai fakta sains Islam dan ilmu yakin sekiranya ia tidak menyanggahi nas wahyu dan tidak menyalahi perkara yang telah disepakati oleh para ulama Islam. Sebaliknya, meskipun keputusan uji kaji merupakan suatu fakta saintifik tetapi andainya ia bersalahan dengan nas wahyu dan melanggar kesepakatan para ulama, maka ia tertolak sebagai fakta sains Islam dan ilmu yakin.

\section{Aplikasi Metodologi Mengenal Alam Daud al-Fatani dalam Penentuan Kenampakan Anak Bulan}

Berasaskan kenyataan hukum adat yang telah diterangkan dan pelarasan faham saintifiknya, dapat dinyatakan bahawa kaedah rukyah dan kaedah hisab kedua-duanya bersifat mungkin. Dalam konteks hukum fiqh, kedua-duanya adalah zannī di mana kaedah hisab lebih kuat berbanding kaedah rukyah. Kaedah rukyah terdedah kepada nilai ralat yang lebih besar disebabkan oleh had pancaindera sedangkan kaedah hisab yang berasaskan kekuatan rasional tidak terkekang dengan had pancaindera. Dari perspektif perkaedahan ilmu Islam, kaedah rukyah adalah paparan sumber empirik sedangkan kaedah hisab memaparkan sumber akal. Berdasarkan konsep alam Daud al-Fatani, kaedah rukyah berada pada alam fizikal, manakala kaedah hisab berada pada alam minda.

Sehubungan dengan itu, dapat dinyatakan bahawa fungsi utama kaedah hisab adalah sebagai mekanisme utama untuk menyusun sistem kalendar Islam dan untuk menunjukkan 
kemungkinan berlakunya kenampakan anak bulan. Jika kaedah hisab memiliki nilai ketepatan yang tinggi, maka kadar kemungkinan untuk kenampakan anak bulan dilihat juga adalah tinggi dan dapat mengatasi keraguan yang munasabah. Ia bukannya berfungsi untuk membuktikan kenampakan anak bulan secara pasti dan muktamad. Ini kerana dalam konteks hukum fiqh, kaedah hisab itu sendiri bersandarkan nas zannī yang terbuka kepada pelbagai pentafsiran dan ia bersifat sangkaan yang membuka ruang perbezaan pemikiran. Dalam konteks astronomi, kaedah hisab yang mengikut kriteria hanya bersifat teori dan bukannya fakta saintifik. Ia melibatkan pelbagai parameter kenampakan anak bulan yang boleh diubah dan hitungannya dipengaruhi oleh kedudukan geografi tempatan.

Mengikut metode berfikir Daud al-Fatani yang dirumus terdiri daripada cerapan dan tasdiq, maka kaedah rukyah merupakan aspek cerapan sedangkan kaedah hisab dapat berperanan sebagai tasdiq. Dalam konteks tasdī $q$ itu, fungsi kaedah hisab dapat diperhalusi secara terperinci iaitu sebagai isbat dan nafi secara serentak terhadap laporan cerapan. Sekiranya laporan cerapan disahkan benar menurut kaedah hisab, maka ketika itu kaedah hisab berfungsi sebagai isbat terhadap kesahan laporan dan menafikan sebarang keraguan. Sebaliknya pula, sekiranya laporan cerapan disahkan tidak benar mengikut kaedah hisab, maka ketika itu kaedah hisab berfungsi sebagai penafi terhadap kesahan laporan dan isbat kepada keraguan yang munasabah.

Berdasarkan keterangan di atas, jelas bahawa fungsi kaedah hisab hanya sebagai tasdiq kepada laporan cerapan khususnya bagi bulan Ramadan, Syawal dan Zulhijjah. Bagaimanakah pula kedudukan kaedah istikmal berbanding kaedah hisab? Kaedah istikmal adalah merujuk kepada penggenapan bilangan bulan qamari kepada 30 hari sekiranya anak bulan tidak dapat kelihatan pada hari ke-29. Ia merupakan kaedah asas yang diikuti oleh jumhur ulama sebagaimana telah disebutkan ${ }^{50}$.

Menurut Ibn Hajar, perintah untuk memulakan puasa adalah jelas bukan menerusi kaedah hisab tetapi berdasarkan hadith yang diriwayatkan oleh Abū Hurairah "jika anak bulan tidak dapat dilihat, maka genapkanlah bulan itu 30 hari". Kemudian, antara

${ }^{50}$ Al-Nawāwī, al-Majmū' Sharh al-Muhadhdhab li al-Shīrāzì, 6:276. 
hikmah penggenapan 30 hari adalah untuk mengelak konflik antara manusia dan ia mampu diketahui oleh setiap mukallaf ${ }^{51}$.

Bagaimanapun, al-Qaraḍāwī berpandangan bahawa kaedah istikmal yang dinyatakan oleh nas hadith bukanlah tujuan utama yang ditekankan. Kaedah tersebut ditunjukkan Nabi Muhammad SAW kerana ia adalah cara yang mudah difahami oleh masyarakat awam ketika itu dan agar tidak menyusahkan mereka. Allah SWT tidak membebankan hambaNya melainkan dengan sesuatu yang mampu dilaksanakan. Pada zaman Rasulullah SAW, kebanyakan masyarakat adalah buta huruf, jika hisab digunakan sudah tentu akan menyulitkan mereka. Kerana itu, hadith menunjukkan metode yang rendah dan mudah iaitu dengan rukyah dan istikmal. Pun begitu, kaedah ini masih mempunyai kemungkinan berlakunya keraguan. Terdapat cara yang lebih baik, mustahil berlakunya kesilapan dan pembohongan serta lebih meyakinkan bagi mencapai tujuan nas tersebut iaitu untuk menentukan kenampakan anak bulan, cara tersebut adalah dengan menggunakan kaedah hisab ${ }^{52}$.

Menurut Shākir ${ }^{53}$, semasa zaman awal Islam jelas bahawa orang Arab tidak mempunyai pengetahuan astronomi secara saintifik. Mereka merupakan satu masyarakat yang buta huruf, maka menulis dan mengira bukanlah menjadi sebahagian budaya mereka. Sesiapa yang mengetahui astronomi pada masa itu hanyalah memahami perkara asas yang diperolehi melalui cerapan, secara tradisi lisan dan laporan. Pengetahuan mereka tentang astronomi tidak berdasarkan pada peraturan matematik dan bukti empirikal. Oleh kerana itu, Nabi Muhammad SAW menetapkan kalendar Islam yang mempunyai keperluan ibadah sesuai dengan ciri-cirinya yang pasti dan boleh dicapai oleh semua orang, iaitu dengan melihat anak bulan menggunakan mata kasar.

Berasaskan pandangan para sarjana itu, kaedah istikmal jelas dilihat sebagai kaedah yang ringkas dan mudah. Golongan yang mendukung hisab berpendapat bahawa 'illah atau sebab untuk pemakaian kaedah istikmal ialah situasi masyarakat Islam yang $u m m \bar{\imath}$ pada zaman Rasulullah SAW. Apabila 'illah itu tidak lagi

\footnotetext{
${ }^{51}$ Al-‘Asqalānī, Fath al-Bārī bi Syarh Ṣaḥ̄ḥ al-Bukhārī, 151-152.

52 Al-Qaraḍāwī, Kayf Nata 'àmal ma 'a al-Sunnah al-Nabawiyyah, 165-166.

${ }^{53}$ Lihat Moosa, "Shaykh Ahmad Shākir and the Adoption of a ScientificallyBased Lunar Calendar," t.h.
} 
wujud iaitu masyarakat telah memiliki kadar celik huruf yang tinggi, maka kaedah rukyah-istikmal boleh digantikan dengan hisab $^{54}$.

Pada pandangan pengkaji, 'illah penggunaan kaedah istikmal bukanlah semata-mata berhubungan dengan situasi ummī masyarakat Islam. Pemakaian kaedah yang cukup ringkas dan asasi itu lebih kukuh dikaitkan dengan penjelasan Rasulullah SAW dalam hadith ummī bahawa bilangan hari untuk satu bulan qamari ialah sesekali 29 hari dan sesekali 30 hari di mana penjelasan terbabit merupakan suatu fakta. Ini kerana dari perspektif astronomi sendiri, tempoh kitaran lengkap bulan mengelilingi bumi iaitu kitaran sinodik ialah 29.530589 hari yakni bersamaan dengan 29 hari 12 jam 44 minit 2.9 saat. Sekiranya bulan tidak kelihatan pada hari ke-29, teknik penggenapan bulan menjadi 30 hari adalah munasabah dengan kitaran sinodik bulan ${ }^{55}$.

Oleh itu, jika kaedah istikmal bersandar kepada fakta ilmiah kitaran sinodik bulan, maka kaedah hisab bergantung dengan pelbagai bentuk parameter yang boleh diubah dan relatif sifatnya. Malah hingga kini, terdapat pelbagai kriteria yang berbeza dipengaruhi oleh pertimbangan yang berlainan ${ }^{56}$.

Kemudian, dalam konteks pendalilan hukum, pentafsiran lafaz faqdurū lah supaya merujuk kepada kaedah istikmal adalah lebih kuat dan terang (sarīh) berbanding kaedah hisab. Ini kerana sandaran kaedah istikmal iaitu frasa fäkmilū al- 'iddah thalathīn yawman ataupun fakmilū 'iddah sha 'bān thaläthīn yang termuat dalam hadith Abū Hurayrah adalah dalālah qaț iyyah sedangkan tafsiran faqdurū lah sebagai kaedah hisab merupakan dalālah zanniyyah ${ }^{57}$.

Oleh yang demikian, jelas bahawa kaedah istikmal mempunyai alasan yang lebih konkrit bukan sahaja berasaskan dalälah qaț'iyyah malah dari kaca mata astronomi ia beriringan

${ }^{54}$ Al-Qaraḍ̄̄īi, Kayf Nata 'āmal ma 'a al-Sunnah al-Nabawiyyah, 165-166.

55 Tilman Spohn et al., Encyclopedia of the Solar System, Ed. 3 (Elsevier, 2014), 495.

${ }^{56}$ Lihat lebih lanjut perbincangan tentang perkembangan kriteria kenampakan anak bulan dan kajiannya pada masa kini dalam Mohammad Ilyas, Sistem Kalendar Islam dari Perspektif Astronomi (Kuala Lumpur: Dewan Bahasa dan Pustaka, 1999), 110.

${ }^{57}$ Abū al-Hasan 'Alī bin Khalaf bin 'Abd al-Mālik bin Bațāal al-Kubrā alQurțūbī, Sharh Sahīh al-Bukhārī (Riyadh: Maktabah al-Rushd, 2003), 4: 27. 
dengan fakta. Adapun kaedah hisab hanya berdasarkan dalālah zanniyyah dan dari perspektif astronomi ia berstatus teori.

Berlandaskan metode berfikir Daud al-Fatani, kaedah istikmal adalah wajib ḍrūrī iaitu "barang yang tiada berkehendak akal pada mendapatkan dia kepada tilik dan kepada bicara". Dalam erti kata yang lain, ia merupakan hakikat ilmiah yang nyata, fakta, objektif, konkrit dan boleh diterima secara universal oleh semua individu yang mencapai tahap akal mumaiyiz. Sedangkan kaedah hisab adalah wajib nazari iaitu "barang yang berkehendak kepada mendapatkan dia itu kepada fikir dan bicara". Ia merupakan hakikat ilmiah yang masih kabur, subjektif dan relatif. Ia hanya dapat difahami secara khusus oleh individu yang mempunyai kekuatan akal rasional. Oleh sebab itu, kaedah istikmal lebih sesuai dinisbahkan sebagai hisab darūrī atau hisab qat ' $\bar{l}$ kerana teknik penggenapan yang diterapkannya itu juga merupakan bahagian ilmu matematik. Manakala kaedah hisab mengikut pendekatan kriteria itu dapat diistilahkan sebagai hisab nazarī atau hisab z̧annī ${ }^{58}$.

Rajah 1: Kaedah Penentuan Kenampakan Anak bulan

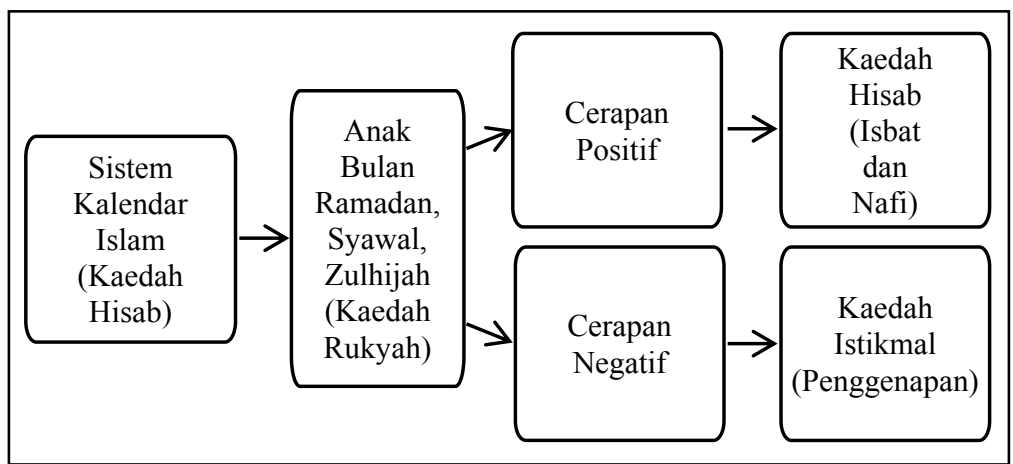

Sumber: Rumusan Pengkaji

Sebagai kesimpulan, rajah 1 di atas menjelaskan fungsi utama kaedah hisab adalah sebagai mekanisme utama dalam penyusunan sistem kalendar Islam dan untuk menunjukkan kemungkinan berlakunya kenampakan anak bulan. Khusus bagi bulan Ramadan, Syawal dan Zulhijjah, penentuan kenampakan anak bulan dibuat berasaskan kaedah rukyah. Sekiranya anak bulan kelihatan di atas

${ }^{58}$ Daud bin Abdullah al-Fatani, al-Durr al-Thamin, 9; Daud bin Abdullah alFatani, al-Durr al-Thamin: Permata Yang Indah, 27-28. 
ufuk barat, maka laporan cerapan itu perlu disahkan menerusi kaedah hisab. Dalam konteks tersebut, kaedah hisab berperanan penting sebagai tasdiq iaitu mengemukakan isbat dan nafi secara serentak. Apabila kenampakan anak bulan diakui kesahannya oleh kaedah hisab, maka fungsi isbat bagi kaedah hisab terserlah pada ketika itu sekaligus menafikan sebarang keraguan terhadap laporan cerapan. Sebaliknya pula, apabila kenampakan anak bulan ditolak kesahannya oleh kaedah hisab, maka fungsi nafi bagi kaedah hisab terserlah ketika itu dan ia menjadi isbat bahawa laporan cerapan mengandungi keraguan yang munasabah.

Contohnya pada tarikh 29 Ramadan $1431 \mathrm{H}$ bersamaan dengan 8 September 2010, cerapan anak bulan untuk menetapkan permulaan bulan Syawal 1431H dilaksanakan di Teluk Kemang, Negeri Sembilan. Semasa matahari terbenam, data kedudukan bulan menunjukkan altitud bulan ialah $-3.211^{\circ}$, sudut elongasi ialah $5.086^{\circ}$ dan umur bulan ialah 0.76 jam. Pada hari tersebut, Pencerap A melaporkan kenampakan anak bulan di ufuk barat. Laporan itu perlu dinilai berdasarkan kriteria Imkanur Rukyah yang digunakan di Malaysia di mana anak bulan dianggap boleh kelihatan apabila, (i) ketika matahari terbenam ketinggian bulan tidak kurang dari $2^{\circ}$ dan sudut elongasi tidak kurang dari $3^{\circ}$, atau (ii) umur bulan tidak kurang daripada 8 jam ketika bulan terbenam. Berasaskan kriteria itu, maka kenampakan anak bulan yang dilaporkan Pencerap A ditolak kerana terdapat keraguan yang munasabah. Pertama, laporan kenampakan tidak memenuhi kriteria yang diaturkan. Kedua, semasa matahari terbenam bulan juga telah terbenam iaitu berada pada altitud $-3.211^{\circ}$. Dalam konteks itu, kaedah hisab jelas berfungsi sebagai penafi kepada laporan kenampakan dan mengisbatkan wujud keraguan yang munasabah. $^{59}$

Hal tersebut menunjukkan kaedah hisab lebih kuat berbanding kaedah rukyah. Ini kerana dari perspektif astronomi kaedah hisab dapat membuat hitungan dengan kebarangkalian yang tinggi menepati kedudukan objek samawi tanpa dipengaruhi oleh faktor psikologi pencerap dan keadaan langit tempatan. Sedangkan keberkesanan kaedah rukyah adalah dipengaruhi oleh faktor terbabit.

${ }^{59}$ Mohammaddin et al., "Kesan Penggunaan Hitungan Astronomi dan Alatan Moden dalam Cerapan Hilal di Malaysia: Satu Penelitian". 
Adapun sekiranya anak bulan tidak kelihatan di ufuk barat, maka ketentuan itu perlu dirujuk kepada kaedah istikmal iaitu menggenapkan bulan kepada 30 hari. Ini kerana kaedah istikmal lebih kuat berbanding kaedah hisab. Dari segi pendalilan, kaedah istikmal berasaskan dalālah qat'iyyah sedangkan kaedah hisab bersandarkan dalālah zanniyyah. Dari perspektif astronomi pula kaedah istikmal berpandukan teknik penggenapan yang selaras dengan kitaran sinodik bulan, manakala kaedah hisab hanya merujuk kepada teori kriteria yang relatif. Hakikatnya, kaedah istikmal dapat diistilahkan sebagai hisab qat 't $\bar{\imath}$ ataupun hisab darūrī, sebaliknya kaedah hisab secara kriteria dapat diistilahkan sebagai hisab zannī ataupun hisab nazarī.

\section{Penutup}

Melalui metodologi mengenal alam yang dikemukakan oleh Daud al-Fatani, kaedah hisab dikenal pasti tabiatnya sebagai zannī yang lebih kuat kehujahannya berbanding kaedah rukyah dan ia lebih lemah berbanding kaedah istikmal. Fungsi kaedah hisab hanya sebagai isbat dan penafi kepada laporan cerapan untuk penentuan kenampakan anak bulan bagi bulan Ramadan, Syawal dan Zulhijjah. Apabila kenampakan anak bulan diakui kesahannya oleh kaedah hisab, maka fungsi isbat bagi kaedah hisab terserlah pada ketika itu sekaligus menafikan sebarang keraguan terhadap laporan cerapan. Sebaliknya, apabila kenampakan anak bulan ditolak kesahannya oleh kaedah hisab, maka fungsi nafi bagi kaedah hisab terserlah ketika itu dan ia menjadi isbat bahawa laporan cerapan mengandungi keraguan yang munasabah.

\section{Bibliografi}

Ahmad Fathy al-Fatani. Ulama Besar dari Patani. Bangi: Universiti Kebangsaan Malaysia, 2002.

Al-Maydān̄̄, 'Abd al-Raḥman Ḥasan Ḥabanakah. Dawābit alMa'rifah wa Ușūl al-Istidlāl wa al-Munāzarah. Damsyik: Dār al-Qalam, 1993.

Al-Muțīìn, Muhammad Bakhīt. Kitāb Irshād Ahl al-Millah ilā Ithbāt al-Ahillah. Kaherah: Maṭba'ah Kurdistan al-'Ilmiyyah, 1911.

Al-Nawāwī, Yahyā̄ Ibn Sharf. Al-Majmū' Sharh al-Muhadhdhab li al-Shīrāzì. Jeddah: Maktabah al-Irshād, 1980. 
Al-Qaraḍāwī, Yūsuf. Fiqh al-Șiyām. Kaherah: Maktabah alWahbah, 2006.

Al-Qaraḍāwī,Yūsuf. Kayf Nata'āmal ma'a al-Sunnah alNabawiyyah. Kaherah: Dār al-Shuruq, 2005.

Al-Quḍāh, Sharaf "Thubūt al-Shahr al-Qamarī bayna al-Ḥadīth alNabawī wa al-'Ilm al-Hadīth" dalam Majallah al-Dirāsah (1999).

Al-Qurțūbī, Abū al-Hasan 'Alī bin Khalaf bin 'Abd al-Mālik bin Bațtạl al-Kubrā, Sharh Saḥ̄h al-Bukhārī. Riyadh: Maktabah alRushd, 2003.

Al-Subkī, Taqī al-Dīn 'Alī bin 'Abd al-Kāfî. Fatāwā al-Subkī fi Furū' al-Fiqh al-Shāfi 'î. Beirut: Dār al-Ma'rifah, 2004.

Al-Zarqā', Muștafā Ahmad. "Hawl I'timād al-Hisāb al-Falakī li Tahdìd Bidāyah al-Shuhūr al-Qamāriyyā: Hal Yajūz Shar'an aw Lā Yajūz?," dalam Majjallāt Majma' al-Fiqh al-Islāmī. T.tp.: Dawrah al-Thāniyah li Mu'tamar Majma' al-Fiqh Islāmī, 1986.

Bruin, F. "The First Visibility of the Lunar Crescent," Vistas in Astronomy, no. 21 (1977).

Daud bin Abdullah Daud bin Abdullah al-Fatani, Diyā al-Murīd (Hāmish al-Durr al-Thamīn). Patani: Mațba'ah Bin Halābī, t.t.

E. S, Bradley. "Visibility of the Lunar Crescent", Quarterly Journal of the Royal Astronomical Society, 29 (1988): 511.

Fauzi Deraman. Hadith dalam karya Syeikh Daud al-Fatani. Kuala Lumpur: Dewan Bahasa dan Pustaka, 2010.

Fotheringham, J. K. "The Visibility of The Lunar Crescent," The Observatory 44 (1921).

Fotheringham, J. K., "On the Smallest Visible Phase of the Moon," Monthly Notices of the Royal Astronomical Society, no. 70 (1910).

Ibn Ḥajar al-'Asqalān̄̄, Aḥmad Ibn 'Ali ibn Muḥammad. Fath alBārī bi Syarh Șahīh al-Bukhārī, ed. 'Abd al-Qādir Syaibah alHamad. Riyadh: Maktabah al-Malik Faḥd al-Wațaniyyah Atsnā' an-Nashr, 2001.

Jawharī, Ṭanțāwī. Al-Qur'ān wa al- 'Ulūm al- 'Asriyyah. Kaherah: Mațba'ah Dār Ihyyā' al-Kutub al-'Arabiyyah, 1923.

Matheson, Virginia dan Barry Hooker, M. "Jawi Literature in Patani: The Maintenance of an Islamic Tradition." Journal of 
the Malaysian Branch of the Royal Asiatic Society 61, no. 1 (1988): 1-86.

Maunder, E. W. "On the Smallest Visible Phase of the Moon," The Journal of the British Astronomical Association, no. 21 (1911).

McNally, D. "The Length of the Lunar Crescent," Royal Astron. Soc. Quarterly Journal 24, no. 4 (1983).

Mohammad Ilyas, "Lunar Crescent Visibility Criterion and Islamic Calendar." Quarterly Journal of the Royal Astronomical Society 35, no. 4 (12 1994): 425-461.

Mohammad Ilyas. Sistem Kalendar Islam dari Perspektif Astronomi. Kuala Lumpur: Dewan Bahasa dan Pustaka, 1999.

Mohammad Ilyas. "Limiting Altitude Separation in The New Moon's First Visibility Criterion." Astronomy and Astrophysics 206, no. 1 (11 1988): 133-135.

Mohammad Ilyas. Kalendar Islam Antarabangsa. Kuala Lumpur: Dewan Bahasa dan Pustaka, 1999.

Mohammad Shaukat Odeh. "New Criterion for Lunar Crescent Visibility." Experimental Astronomy 18, no. 1-3 (2004): 39-64.

Mohammaddin Abdul Niri et. al. "Kesan Penggunaan Hitungan Astronomi dan Alatan Moden dalam Cerapan Hilal di Malaysia: Satu Penelitian." Jurnal Fiqh 9 (2012): 45-64.

Mohd Saiful Anwar Mohd Nawawi, Mohammaddin Abdul Niri dan Mohd Zambri Zainuddin. "Kenampakan Anak Bulan di Teluk Kemang: Analisis Mengikut Pandangan Fiqh oleh Yusuf al-Qaradawi dan Perspektif Astronomi." Jurnal Syariah 21, no. 1 (2013): 63-73.

Mohd Saiful Anwar Mohd Nawawi. "Penilaian Semula Kriteria Kenampakan Anak Bulan di Malaysia, Indonesia Dan Brunei." Tesis kedoktoran, Universiti Malaya, 2014.

Moosa, Ebrahim, "Shaykh Ahmad Shākir and the Adoption of a Scientifically-Based Lunar Calendar," Islamic Law and Society 5, no. 1 (1998), t.h.

Muḥammad Shākir, Aḥmad. Awā'il al-Shuhūr al-'Arabiyya: Hal Yajūz Shar'an Ithbātuhā bi al-Hisāb al-Falakī? Bahth Jadīd 'Ilmī Hurr. Kaherah: Dār al-Istiqāmah, 1992.

S. K, Ayman. "The Psychological Effect on Sightings of the New Moon", The Observatory, 123 (2003), 219-222. 
Schaefer, B. E. "An Algorithm for Predicting the Visibility of the Lunar Crescent," Bulletin of the American Astronomical Society 19.

Tilman Spohn et al., Encyclopedia of the Solar System. Ed. ke-3. Elsevier, 2014), 495.

Wan Mohd. Shaghir Abdullah, Syeikh Daud Bin Abdullah alFatani: Ulama' dan Pengarang Terulung Asia Tenggara. Shah Alam: Hizbi, 1990.

Wan Mohd. Shaghir Abdullah. "Sejarah Ringkas Syeikh Daud bin Abdullah al-Fatani dan Karya-karyanya," dalam Kertas kerja Nadwah Ilmiah Tokoh Ulama Peringkat Kebangsaan Kali ke-4, Pusat Islam Kuala Lumpur, 17-19 Disember, 199113. 